\title{
COMPLIMENTARY
}

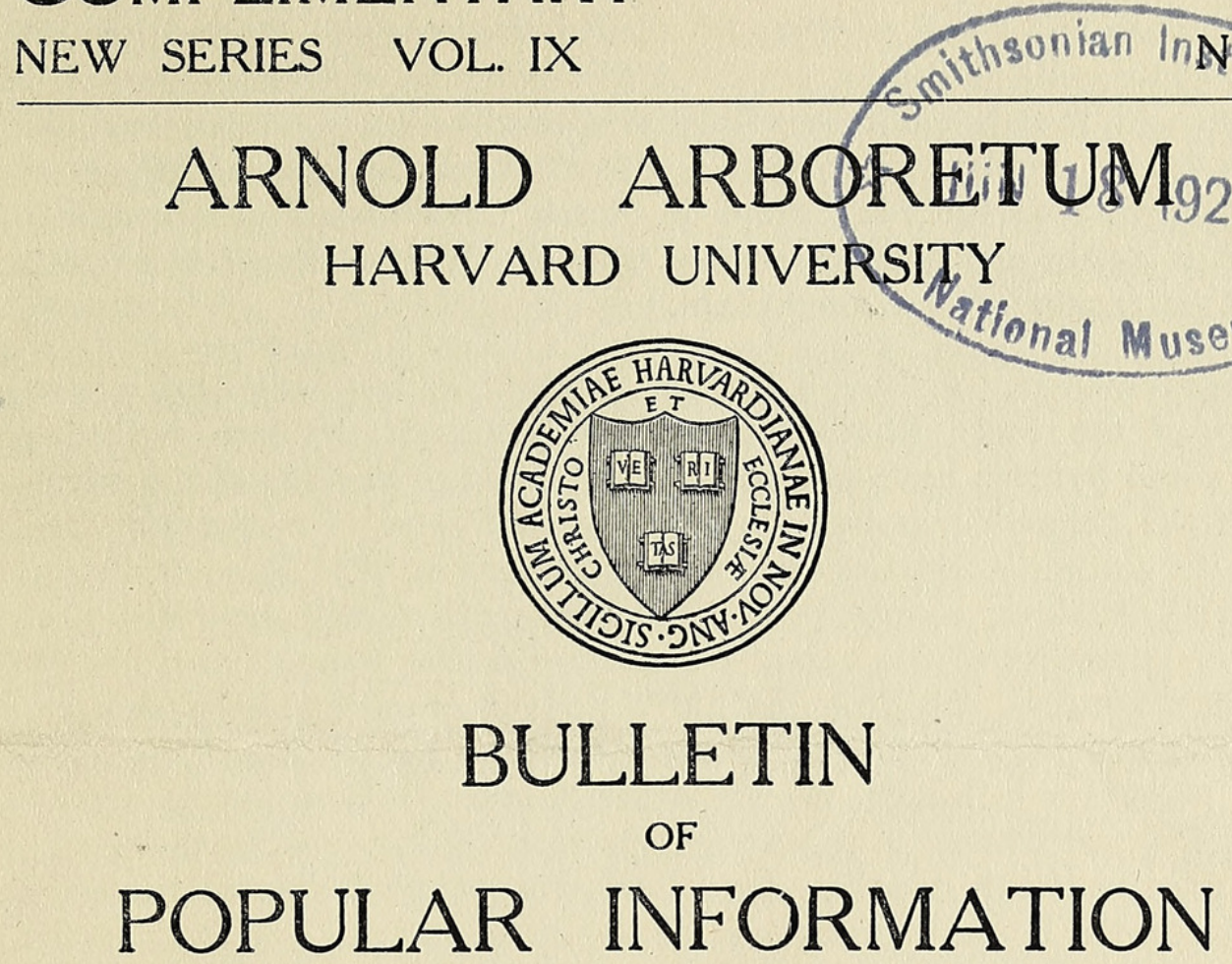

JAMAICA PLAIN, MASS.

JUNE 15,1923

The Mountain Laurel (Kalmia latifolia) at the northern base of Hemlock Hill is well covered with flower-buds which will have opened when this Bulletin reaches its Massachusetts readers. The flowering of the Laurels is the last of the great Arboretum flower shows of the year, and none of those which precede it are more beautiful, for the Mountain Laurel or the Calico Bush as it is often called, is in the judgment of many flower-lovers the most beautiful of all North American shrubs or small trees. Many Rhododendrons have larger leaves and larger and more brilliantly colored flowers, but of all the broad-leaved evergreen plants which can be grown successfully in this climate the Laurel is the handsomest and most satisfactory. It is not perhaps strange that so little attention has been paid to it by American gardeners, for the American gardeners, of the earlier generations at least, derived their inspiration almost entirely from England, and usually despised American plants as too common for their attention. For some reason which is not easy to explain Kalmia latifolia has never been a popular plant in England where it is still not often seen and where it certainly grows less freely than many species and hybrids of Rhododendron. For this reason, perhaps, no distinct forms of the Laurel and no hybrids have been developed by cultivators and the few recognized variations in the flowers and leaves have all been found on wild plants. Of these there are forms with pure white flowers (var. $a l b a$ ), and there is a form with deep pink, nearly red flowers and rather dark leaves (var. rubra). Between these extremes there are others with flowers of all shades of pink, and there is one with flowers conspicuously marked by a chocolate band (var. fuscata). There is a dwarf form (var. myrtifolia) with 
small leaves and small clusters of minute flowers; and there is one in which the corolla is deeply divided into narrow lobes (var. polypetala). A form with broad, handsome, Rhododendron-like leaves (var. obtusata), rarely flowers, and another with a six-lobed corolla has recently been found growing on the Blue Ridge in North Carolina. The Laurel collection is easily and quickly reached from the Walter Street and South Street entrances of the Arboretum.

Rhododendrons. Although the hot weather of last week ruined the flowers of the early Rhododendrons and although the late flowering species and hybrids have not yet opened, a large number of the varieties of the Catawbiense hybrids are now in bloom. Persons who may desire to cultivate Rhododendrons must remember that they, including nearly all Azaleas, cannot live in soil impregnated with lime and that with the exception of the native $R$. maximum they are not hardy north of Massachusetts, and that south of Maryland, except at high altitudes on the Appalachian Mountains, the summers are too hot for them. The range therefore in eastern North America where these plants can be successfully cultivated is comparatively small, but probably the northwest coast of North America from southern British Columbia to northern California is as well suited for these plants as any part of the world, and in this region there can be grown in addition to all the varieties common in European gardens the Himalayan and Chinese species which here in the east can only be kept alive in glass houses, and in Europe thrive only in a few exceptionally favorable places like Cornwall or in the neighborhood of the Italian Lakes.

Rhododendrons, although they are moisture-loving plants, do not thrive in undrained positions; they do best in soil in which loam, peat and sand have been equally mixed, although peat is not always essential to the successful cultivation of these plants. They should be planted where the roots of trees cannot take away moisture from them, and the best position for these plants is on the north side but not too near coniferous trees as they have been planted in the Arboretum. In such positions they are protected from the direct rays of the sun in March and April, for in this climate where the roots are in frozen ground in winter and therefore cannot take up moisture, it is important to reduce as much as possible winter and early spring evaporation from the leaves. It is this evaporation from the leaves of evergreens growing in frozen soil which makes it impossible to keep alive many of them in this part of the country; and this is the reason why it is desirable here to water thoroughly Rhododendrons just before the ground freezes in the autumn. Of the species of evergreen Rhododendrons only the eastern American $R$. maximum, $R$. catawbiense, $R$. carolinianum and its variety with white flowers (var. album), $R$. minus and its mountain form, the Caucasian $R$. Smirnovii and $R$. caucasicum at least in some of its forms, are truly hardy in Massachusetts. The two species of the European Alps, $R$. hirsutum and $R$. ferrugineum can live here sometimes for a number of years, but they are usually short-lived and unsatisfactory plants in this climate. The Japanese $R$. brachycarpum formerly lived in Massachusetts gardens for many years and longer trials will probably show that it can be successfully cultivated in this climate. Including this still doubtful Japanese species and the two 


\section{$2 \mathrm{BHL}$ Biodiversity Heritage Library}

1923. "The Mountain Laurel." Bulletin of popular information - Arnold Arboretum, Harvard University 9(9), 33-34. https://doi.org/10.5962/p.321370.

View This Item Online: https://www.biodiversitylibrary.org/item/239239

DOI: https://doi.org/10.5962/p.321370

Permalink: https://www.biodiversitylibrary.org/partpdf/321370

\section{Holding Institution}

Smithsonian Libraries

\section{Sponsored by}

Biodiversity Heritage Library

\section{Copyright \& Reuse}

Copyright Status: Public domain. The BHL considers that this work is no longer under copyright protection.

Rights Holder: Arnold Arboretum of Harvard University

This document was created from content at the Biodiversity Heritage Library, the world's largest open access digital library for biodiversity literature and archives. Visit BHL at https://www.biodiversitylibrary.org. 